DOI: 10.12731/2658-6649-2019-11-5-2-40-44

УДК 616.155.2

\title{
ОСОБЕННОСТИ ХЕМИЛЮМИНЕСЦЕНТНОЙ АКТИВНОСТИ ТРОМБОЦИТОВ В НОРМЕ И ПРИ ИШЕМИЧЕСКОЙ БОЛЕЗНИ СЕРДЦА
}

\author{
Дубынина Ю.А., Гвоздев И.И., Гончаров М.Д.
}

Целью исследования явилось изучение особенностей хемилюминесиентной активности тромбоцитов в норме и при ишемической болезни сердиа. В исследование приняли участие 35 больных ИБС и 16 относительно здоровых людей. Объект изучения - периферическая кровь. Результатом стали достоверные различия в интенсивности свечения тромбочитов. У больных наблюдается повышенное свечение, а значит и увеличенное продукция активных форм кислорода. Данную особенность хемилюминесиенции связываем с изменением функииональной активности клеток при ИБС.

Ключевые слова: ишемическая болезнь сердиа; активные формы кислорода; тромбоциты; метаболизм.

\section{CHARACTERISTICS OF PLATELET CHEMILUMINESCENT ACTIVITY IN NORMAL AND WITH ISCHEMIC HEART DISEASE}

\section{Dubynina Yu.A., Gvozdev I.I., Goncharov M.D.}

The aim of the study was to study the characteristics of the chemiluminescent activity of platelets in normal and coronary heart disease. The study involved 35 patients with coronary artery disease and 16 relatively healthy people. The object of study is peripheral blood. The result was significant differences in the intensity of luminescence of platelets. Patients have increased luminescence, and therefore increased production of reactive oxygen species. This feature of chemiluminescence is associated with a change in the functional activity of cells in CHD.

Keywords: coronary heart disease; reactive oxygen species; platelets; metabolism. 


\section{Введение}

На сердечно-сосудистые заболевания приходится доминирующая часть смертей во всём мире. По данным Всемирной Организации Здравоохранения ежегодно только по причине ишемической болезни сердца (ИБС) погибают более 7 млн. человек.

Большое значение в патогенезе ИБС имеют нарушения функции тромбоцитов и повышение свертываемости крови [2]. В связи с тем, что тромбоциты способны вырабатывать активные формы кислорода (АФК) в интактном и в активированном состоянии, представляется возможным оценить изменения функциональной активности тромбоцитов по интенсивности продукции АФК.

\section{Материалы и методы}

Для определения интенсивности синтеза АФК применили метод хемилюминесценции (ХЛ), дополнительно использовали зонды: люминол и люцигенин, затем производили регистрацию свечения на хемилюминометре CL 3607 [3].

Данный метод позволяет оценить функциональное состояние тромбоцитов по их способности продуцировать активные метаболиты кислорода [4]. Исследование проводилось в лаборатории НИИ «Медицинских проблем Севера», объектом исследования стала периферическая кровь 35 больных ИБС и 16 относительно здоровых людей.

Результаты ХЛ-анализа характеризовали по следующим параметрам: времени выхода на максимум интенсивности (Tmax), максимальному значению интенсивности $(\operatorname{Imax})$ и площади (S) под ХЛ-кривой. Усиление XЛ, индуцированной АДФ, оценивали соотношением площади индуцированной (S2) к площади спонтанной (S1) и определяли, как индекс активации. Для всех данных определяли медиану (Me) и интерквартальный разброс в виде подсчета 25- (C25) и 75-процентилей (C75). Достоверность различий между группами оценивалась при помощи непараметрического критерия Манна-Уитни [5].

\section{Результаты}

При исследовании спонтанной ХЛ достоверно выявлено, что интенсивность свечения $(\mathrm{p}=0,002)$ и площадь под ХЛ-кривой $(\mathrm{p}=0,011)$ у больных ИБС выше по сравнению с контролем. АДФ-индуцированная хемилюминесценция по всем показателям выше: значения интенсивности свечения $(\mathrm{p}<0,001)$ и площадь под ХЛ-кривой $(\mathrm{p}=0,002)$ люминол-зависимой хемилюминесценции у больных ИБС выше примерно в 2 раза. 


\section{Обсуждение}

Исследование люминол-зависимой ХЛ тромбоцитов позволяет оценить интенсивность продукции всего пула АФК. Так увеличение максимума интенсивности спонтанной и АДФ-индуцированной ХЛ свидетельствует об увеличении максимальной продукции АФК в единицу времени в состоянии относительного покоя и при дополнительной стимуляции in vitro. Площадь под кривой характеризует суммарную продукцию АФК за 90 минут исследования, следовательно, в тромбоцитах больных ИБС усиленная продукция АФК сохраняется в течении 90 минут и не наблюдается истощения метаболических резервов клеток.

\section{Заключение}

Повышения значений ХЛ в пробах больных относительно здоровых, свидетельствует о важной роли АФК в метаболических процессах тромбоцитов. Предполагается участие в регуляции агрегации и дезагрегации этих клеток при ИБС. Также установлено, что интактные тромбоциты способны постоянно генерировать супероксидные радикалы, а значит супероксид зависимая активация тромбоцитов важна в физиологических и патологических гемостатических реакциях. Показано, что изменение концентраций АФК в тромбоцитах связано с их функциональной активностью [6].

\section{Список литературы}

1. Акимова Е.В. Ишемическая болезнь сердца и ее факторы риска в Тюмени: распространенность, динамика, прогнозирование // Автореф. дисс. ... д-ра м.н. Томск. 2003. С. 46.

2. Гринштейн Ю.И., Савченко А.А., Гринштейн И.Ю., Савченко Е.А. Особенности гемостаза, метаболической активности тромбоцитов и частота резистентности к аспирину у больных с хронической сердечной недостаточностью после аортокоронарного шунтирования // Кардиология. 2008. № 6(48). C. 51-56.

3. Савченко А.А., Здзитовецкий Д.Э., Борисов А.Г., Лузан Н.А. Хемилюминесцентная и энзиматическая активность нейтрофильных гранулоцитов у больных распространенным гнойным перитонитом в зависимости от исхода заболевания // Вестник Российской академии медицинских наук. 2014. № 5-6 (69). C. 23-28.

4. Савченко А.А., Кудрявцев И.В., Борисов А.Г. Методы оценки и роль респираторного взрыва в патогенезе инфекционно-воспалительных заболеваний // Инфекция и иммунитет. 2017. № 4(7). С. 327-340. 
5. Негреску Е.В., Лебедев А.В., Балденков Г.Н. Антиоксиданты, перекисное окисление липидов и рецепторзависимое увеличение концентрации кальция в тромбоцитах человека // Вопросы медицинской химии. 1992. №2. С. 36-39.

6. Кривохижина Л.В., Кантюков С.А., Ермолева Е.Н., Кривохижин Д.Н. Хемилюминесценция тромбоцитов, использование метода хемилюминесценции для определения активности тромбоцитов // Вестник Тюменского государственного университета. 2013. №6. С. 23-28.

\section{References}

1. Akimova E.V. Ishemicheskaya bolezn'serdca i ee factory riska v Tyumeni rasprostranennost dinamika prognozirovanie [Ischemic Heart Disease and its Risk Factors in Tyumen: Prevalence, Dynamics, Prediction]. Tomsk. 2003. P. 46.

2. Grinshteyn Yu.I., Savchenko A.A., Grinshteyn I.Yu., Savchenko Ye.A. Osobennosti gemostaza, metabolicheskoy aktivnosti trombotsitov i chastota rezistentnosti $\mathrm{k}$ aspirinu u bol'nykh s khronicheskoy serdechnoy nedostatochnost'yu posle aortokoronarnogo shuntirovaniya [Features of hemostasis, metabolic activity of platelets and the frequency of aspirin resistance in patients with chronic heart failure after coronary artery bypass surgery]. Kardiologiya. 2008. № 6(48), pp. 51-56.

3. Savchenko A.A., Zdzitovetskiy D.E., Borisov A.G., Luzan N.A. Khemilyuminestsentnaya i enzimaticheskaya aktivnost' neytrofil'nykh granulotsitov u bol'nykh rasprostranennym gnoynym peritonitom $\mathrm{v}$ zavisimosti ot iskhoda zabolevaniya [Chemiluminescent and enzymatic activity of neutrophilic granulocytes in patients with common purulent peritonitis, depending on the outcome of the disease]. Vestnik Rossiyskoy akademii meditsinskikh nauk. 2014. № 5-6 (69), pp. 23-28.

4. Savchenko A.A., Kudryavtsev I.V., Borisov A.G. Metody otsenki i rol' respiratornogo vzryva $\mathrm{v}$ patogeneze infektsionno-vospalitel'nykh zabolevaniy [Evaluation methods and the role of the respiratory explosion in the pathogenesis of infectious and inflammatory diseases]. Infektsiya i immunitet. 2017. № 4(7), pp. 327-340.

5. Negrescu E.V., Lebedev A.V., Baldenkov G.N. Antioksidanty perekisnoe okislenie lipidov i receptorzavisimoe uvelichenie koncentracii kalciya vtrombocitah cheloveka [Antioxidants, lipid peroxidation and receptor-dependent increase in calcium concentration in human platelets]. Questions of Medical Chemistry. 1992. №2, pp. 36-39.

6. Krivokhizhin L.V., Kantyukov S.A., Ermoleva E.N., Krivohizhin D.N. Hemilyuminescenciya trombocitov ispolzovanie metoda hemilyuminescencii dlya opredeleniya aktivnosti trombocitov [Chemiluminescence of platelets, using the chemiluminescence method for determining platelet activity]. Bulletin of Tyumen State University. 2013. №6, pp. 23-28. 


\section{ДАННЫЕ ОБ АВТОРАХ}

Дубынина Юлия Алексеевна, студент ИФБиБТ, 4 курс, кафедра медицинской биологии СФУ пр. Свободный, 79, г. Красноярск, 660041, Российская Федерачия Dubynina_y@mail.ru

Гвоздев Иван Игоревич, младший научный сотрудник лаборатории клеточно-молекулярной физиологии и патологии ФГБНУ «НИИ медицинских проблем Севера» ул. Партизана Железняка, 3 2, г. Красноярск, 660022, Российская Федераиия Leshman-mult@mail.ru

Гончаров Максим Дмитриевич, врач Федеральный центр сердечно-сосудистой хирургии МЗ РФ ул. Караульная, 45, г. Красноярск, 660020, Российская Федераиия adimax07@mail.ru

\section{DATA ABOUT THE AUTHORS}

Dubynina Yuliya Alekseevna, student, 4 course, Department of Medical Biology

Siberian Federal University

79, Svobodny Ave., Krasnoyarsk, 660041, Russian Federation

Dubynina_y@mail.ru

Gvozdev Ivan Igorevich, Junior Research Officer of the Laboratory of Cell Molecular Physiology and Pathology Research Institute for Medical Problems of the North 3g, Partizan Zheleznyak Str., Krasnoyarsk, 660022, Russian Federation

Leshman-mult@mail.ru

Goncharov Maxim Dmitrievich, doctor

Federal Center for Cardiovascular Surgery, Ministry of Health of the Russian Federation 45, Karaulnaya str., Krasnoyarsk, 660020, Russian Federation adimax07@mail.ru 